Review

\title{
Sustainable Buildings: An Ever Evolving Target
}

\section{Yvan Dutil*, Daniel Rousse and Guillermo Quesada}

Technologies of Energy and Energy Efficiency (T3E), École de Technologie Supérieure, 201 Boul. Mgr, Bourget, Lévis, QC, G6V 6Z3, Canada; E-Mails: daniel@t3e.info (D.R.); guillermo@t3e.info (G.Q.)

* Author to whom correspondence should be addressed; E-Mail: yvan@t3e.info; Tel.: +1-418-835-2110; +1-418-823-2112.

Received: 3 December 2010; in revised form: 24 January 2011 / Accepted: 26 January 2011 / Published: 16 February 2011

\begin{abstract}
Environmental considerations have called for new developments in building technologies to bridge the gap between this need for lower impacts on the environment and ever increasing comfort. These developments were generally directed at the reduction of the energy consumption during operations. While this was indeed a mandatory first step, complete environmental life cycle analysis raises new questions. For instance, for a typical low thermal energy consumption building, the embodied energy of construction materials now becomes an important component of the environmental footprint. In addition, the usual practice in life cycle analysis now appears to call for some adaptation-due to variable parameters in time - to be implemented successfully in building analysis. These issues bring new challenges to reach the goal of integrated design, construction, commissioning, operation, maintenance, and decommissioning of sustainable buildings.
\end{abstract}

Keywords: sustainable building; passivhaus; life cycle assessment

\section{Introduction}

Sustainable development as defined in Brundtland's report [1], is a "development that meets the needs of the present without compromising the ability of future generations to meet their own needs". Today, climate change and resources scarcity, combine with this need to have an ever "growing" economy threaten our ability to reach this goal. 


\subsection{Reducing Energy Consumption}

In response to the need of a sustainable economy, reduction of energy consumption in general and fossil fuel in particular is a global acknowledged priority. To mitigate climate change, the world needs to reduce the $\mathrm{CO}_{2}$ emission by $50 \%$ from the current level by 2050 . For developed countries, this translates into a reduction of $80 \%$, a factor five with respect to nowadays emissions [2]. To reach this goal, some authors have proposed to drastically reduce the energy consumption. For example, Kesselring and Winter [3] proposed the concept of a 2,000 W society which aims at consuming no more than what corresponds to an average continuous power of 2,000 W per capita. This concept was later further developed and expanded [4,5]. Since actual rates of energy consumption is about 6,000 W in Europe and even 10,000 W in North America, this would imply a reduction by a factor 3 to 5 of the energy consumption per capita.

The building industry is one of the human activities with the largest environmental impact. As noted by Dixit et al. [6], the construction industry depleted two-fifths of global raw stone, gravel, and sand; one-fourth of virgin wood; and it consumes 40 percent of total energy and 16 percent of fresh water annually [7-13]. These figures are more or less similar in any developed country. Indeed, for OECD countries, energy consumption by building varies between $25 \%-50 \%$ of total energy consumption [14], whereas it is closer to 50\% in the European Union [15].

To reduce this tremendous demand and consequent impacts, the European Union Directive on Energy Performance of Buildings [16] requires member states to implement energy efficiency legislations for buildings, including existing ones with floor areas over $1,000 \mathrm{~m}^{2}$ that undergo significant renovations. In a similar way, the Swedish government promulgated a Bill on Energy Efficiency and Smart Construction, to reduce total energy use per heated building area by $20 \%$ by 2020 and $50 \%$ by 2050, using year 1995 as the reference [17]. In addition, these energy efficiency measures offer a significant opportunity to reduce $\mathrm{CO}_{2}$ emissions $[2,18]$.

In conclusion, reducing our global consumption necessarily calls for an improvement in the building industry.

\subsection{Zero Energy Buildings}

Technologies for energy efficient housing have a long history. One of the first designs of zero energy houses was the 1939 MIT Solar House I, which included a large solar thermal collector area and water storage [19].This project was followed by the "Bliss House" of 1955 using solar air collectors and rock mass storage [20]. Other projects followed in the 70's: for instance, the Vagn Korsgaard Zero Energy Home in Denmark in 1977 [21] or the Saskatchewan Conservation House in 1979 [22]. These designs proposed buildings that had a close to zero heating need all over the year. This was achieved mainly and logically by highly insulated envelopes. Approaches that prefigure modern "passivhaus" design, like good air tightness (1.3 air changes at $50 \mathrm{~Pa}$ ) and consequently an air-to-air heat exchanger, were used some 30 years ago in the Saskatchewan Conservation House.

The first passive house in Germany, designed by Dr. Wolfgang Feist, was built in 1991 in Darmstadt-Kranichstein. This type of designs and similar ones tend to result in the use of less material than previously more requiring zero energy designs, and this makes the "so-called" passivhaus more suitable for large scale implementations. 
With these achievements in mind, new, more restrictive energy standard were established. Hence, in central Europe countries, including Germany and Austria, the maximum final energy use for space heating required to comply with the passive house standard is nowadays $15 \mathrm{kWh} \mathrm{m}^{-2} \mathrm{yr}^{-1}$, and the maximum overall operating primary energy use is $120 \mathrm{kWh} \mathrm{m}^{-2} \mathrm{yr}^{-1}$ [23]. In Sweden, the equivalent requirement is based on purchased energy and is set at 45 and $55 \mathrm{kWh} \mathrm{m}^{-2} \mathrm{yr}^{-1}$ for the South and North Climate zones, respectively [24,25].

\subsection{The Need of Other Means to Reduce a Building Environmental Impact}

Notwithstanding the relevance and importance of those policies, they all focus on the energy consumption through the usage phase, while the building is in operation. Although this is an important factor in the overall environmental impact, focuses are now shifted to other aspects of building environmental impacts (mainly construction, maintenance, and decommissioning). However, since these points were less important in the past, they are not as much documented and formalized than the strict energy consumption in the operation phase. In addition, classical environmental indicators are not optimized for long lifetime goods like buildings, which brings several new, interdependent, hard to solve problems (see Section 6) All these factors bring new challenges to the development of better practices in sustainable building design.

\section{Building Life Cycle Assessment}

\subsection{Life Cycle Analysis}

As mentioned above, beyond the sole energy consumption of a building, other issues have to be considered to account for their global environmental impacts or footprint. This is why a full life cycle analysis (hereafter LCA) is commonly used to assess better design practices. This approach takes into account all of the aforementioned aspects of the building life: construction, commissioning, operation, maintenance, and decommissioning.

Nevertheless, instead of doing a complete LCA, total energy consumption is often used as a proxy. Indeed, the gross energy requirements [26], non-renewable energy, global warming potential—as an indicator of greenhouse emissions with a time horizon of 100 years [2] - are seen as essentially equivalent [27]. This can naturally be justified since energy production is in general a preponderant source of greenhouse gas emission and also because energy consumption reduction by itself represents an objective to achieve sustainability. Notwithstanding this strong correlation between these indicators, there are also other environmental impacts that are taken into account in a LCA (For example: resource depletion). However, Blengini and Di Carlo [28] remarked that there is neither consensus on weighting [29-34], nor on the best weighting method to integrate all the environmental impacts in a global indicator.

\subsection{Low Energy Buildings (Operation)}

As pointed out by Blengini and Di Carlo [34], low energy buildings should use low quantities of energies regardless of the sources. In addition, Sartori and Hestnes [35] noted than one must differentiates between primary and secondary energy consumption. Quoting Feist [36], they observed 
that the definition of a low-energy building as one having an annual requirement for heating below $70 \mathrm{kWh} \mathrm{m}^{-2} \mathrm{yr}^{-1}$ could be misleading. Indeed, an overall end-use consumption, which includes all energy consumption of $120 \mathrm{kWh} \mathrm{m}^{-2} \mathrm{yr}^{-1}$ is typical for those building. This translates in the equivalent of $200 \mathrm{kWh} \mathrm{m}^{-2} \mathrm{yr}^{-1}$ once converted into primary energy. This lead Sartori and Hestnes [35] to refine the definition of a low energy building as one having an operating energy $<120 \mathrm{kWh} \mathrm{m}^{-2} \mathrm{yr}^{-1}$ when expressed in end-use energy, or $<200 \mathrm{kWh} \mathrm{m}^{-2} \mathrm{yr}^{-1}$ when expressed in primary energy.

Far from being semantic, this modification of the definition has many practical consequences. First, it allows for a more direct comparison between the contribution of embodied energy and the consumption of energy over the operational lifetime of the building. Second, this redefinition also means that it takes also account of the nature of the energy used. The largest impact is on the electricity consumption, for which the conversion factor depends on the local production basket. Third, as discussed later, this conversion factor will also change with time as the efficiency of thermal power plant will improve with time and as the fraction of renewable energy source will increase.

\subsection{Embodied Energy (Construction)}

Historically, the contribution of embodied energy was considered minimal compared to energy consumption trough the operational phase [33,35,37-42]. However, for low energy houses, this is not the case as the lifetime energy consumption is much lower while the embodied energy is higher due to additional-sometimes pretty sophisticated - construction materials, energy production and recovery systems [30,35,43-48]. Nevertheless, embodied energy can also have a significant impact in conventional designs in clement weather conditions as observed by Treloar et al. [49], for a two bedroom house located in Australia or for an office building in Greece [50].

Indeed, it has been argued that embodied energy was somehow a substitute to operating energy: therefore the overall gain in efficiency was not as impressive [36]. This situation lead Feist [36] to distinguish between "green" houses for which care is taken to reduce the utilization of synthetic materials, and "low energy" houses that have only for objective the reduction of energy consumption through the operation phase. In this specific case, the embodied energy was somewhat higher than in the conventional design for the "green" house. This is due to the utilization of cellulose fiber as the insulation material, for which the embodied energy was largely increased by the addition of fire retardant materials. For the solar house (the low energy case), the embodied energy requirement was double of that of the classical design while reducing the total energy demand by $50 \%$ over a 50 years lifetime. However, as noted by Sartori and Hestnes [35], a much simpler design - the passivhauscould have achieved a factor three in total energy demand reduction and even a factor four for an improved design.

\subsection{Total Energy Consumption}

Blengini and Di Carlo [28] came to a very similar conclusion when comparing a standard house to its low energy counterpart. The low energy version allowed a reduction of the heating requirement by a factor 10. This ratio was maintained when carrying out a cradle-to-gate perspective. However, when considering the whole building operation phase, therefore adding sanitary water, cooking, lighting and use of appliances, the ratio between the two houses dropped from 10:1 to 3.7:1. Moreover, when 
considering the full life cycle, the ratio was reduced to $2.5: 1$ in terms of energy requirement, 2.4:1 in terms of global warming potential, and 2.3:1 in terms of Ecoindicator 99 [51]. In another work, theses authors [34] observed that, while the heating requirement of a low energy house was reduced by a factor 10 compare to a standard design, the life cycle energy was only reduced by 2.1:1 and the carbon footprint by 2.2:1. Moreover, with a global perspective the environmental trace is no longer dominated by a single major point but is spread through several items. As a result, the designer must not only concentrate his effort on the energetic performance but also on the embodied energy in the building material and their eventual disposal at the end of life of the building. These authors also found that transportation of the building components was only a minor contributor to the environmental trace [34], confirming the previous result of Peuportier [52].

This conclusion is shared by Gustavsson and Joelsson [53], who studied primary energy use and $\mathrm{CO}_{2}$ emission for the production and operation of conventional and low-energy residential buildings in Sweden. They showed that for conventional and low-energy buildings, the primary energy used for production can reach $45 \%$ and $60 \%$, respectively. The importance of the production stage favored the use of wood frames to reduce the environmental trace. They also pointed out that the most effective measure was to improve the building envelope. Indeed, the improvement of the attic insulation and the use of energy-efficient windows provide energy savings 10 times larger than the energy needed for their fabrication.

A similar conclusion was obtained by Verbeeck and Hens [54], who carried-out an analysis of the impact of the embodied energy on the LCA. They pointed out that for the four types of dwelling they studied in Belgium, the additional embodied energy added to improve the energetic performance was recovered in very short terms ( $<2 \mathrm{yr}$ ). Only on extremely low energy building $\left(900 \mathrm{MJ} / \mathrm{m}^{3}\right.$ over $30 \mathrm{yr}$ ), the impact of embodied energy was larger than the energy consumed. As in previous studies, they noted that the return on energy invested (EROI) of insulation is about 10 for a $30 \mathrm{yr}$ period when applied to a building that complies with the legal energy performance level.

Bribián, Uséon and Scarpellini [55] did also take account of the embodied energy in a life cycle assessment for a Spanish building. In their study, the embodied energy represented $30 \%$ of the primary energy used over a $50 \mathrm{yr}$ lifetime. They also proposed an optimization process for the insulation level on the life time energy consumption. Their analysis indicates that a broad optimum design exists, which allows to minimize the heating and cooling loads as embodied energy. This robustness in the result provides some leeway for architectural integration.

In a study of a residential building, Utama and Gheewala [56] demonstrated that a double wall was more energy efficient over a 40 years period than a single wall. Nevertheless, the initial embodied energy of typical double wall and single wall envelopes for high-rise residential buildings is $79.5 \mathrm{GJ} / \mathrm{m}^{2}$ and $76.3 \mathrm{GJ} / \mathrm{m}^{2}$, respectively. This small difference in embodied energy is overwhelmed by the expected energy savings; the energy consumption dropping from $480 \mathrm{GJ} / \mathrm{m}^{2}$ to $283 \mathrm{GJ} / \mathrm{m}^{2}$. In this study [56], the authors raised an interesting point: in this specific case, not only the thermal conductivity of the wall had to be taken into account but also its thermal inertia. Previously, Radhi [57] made the same observation that some of the extra energy consumed by a cooling load is not merely due to the effect of external heat through the envelope and incident heat; rather it is a result of the heat being stored into the building structure (inertia). This illustrates the need for a refined and accurate simulation of a building to be really able to optimize its design. 


\subsection{Life Cycle Zero Energy Buildings}

Hernandez and Kenny [58] extended the idea of a net-zero energy building to the life cycle zero-energy building (LC-ZEB). As defined by the European Parliament, a net-zero-energy building is "a building where, as a result of the very high level of energy efficiency of the building, the overall annual primary energy consumption is equal to or less than the energy production from renewable energy sources on site" [16]. Two other definitions are often used: 'net-zero site energy' and 'net-zero source energy'. The first definition takes only account of the energy exchange over the year. The second definition is somewhat more precise as it takes account of the primary energy. Hence, energy source substitution might allow for a larger amount of energy consumption of heating if electricity is replaced by natural gas [59]. By extension, a life cycle zero energy building includes embodied energy of the building and its components together with the annual energy use. Overall, these energy expenses must be completely compensated by the energy generated by the building over its lifetime.

To reach the goal of a life cycle zero energy building, embodied energy, energy consumption, and production over the lifetime of the house must be analyzed. As we have noted previously, this was not a standard practice for low energy house until recently. Consequently, many components of very-low energy buildings are probably over designed. Using this methodology, Hernandez and Kenny [60,61] argued that solar collectors and high levels of insulation were often not the most efficient way to reduce the life cycle energy of some buildings.

As the awareness of the importance of embodied energy in low energy buildings is growing, critics of the actual evaluations methods follow the same trajectory. Indeed, Dixit et al. [6] also emphasize on the importance of embodied energy in the overall life cycle of housing. However, they noted the problem of the absence of reliable templates, standards or protocols regarding embodied energy computations. Especially, they observed that while the geographic location is commonly stated, the nature of feedstock energy is rarely provided. In addition, the aging of the LCA data is problematic as it creates inconsistencies between studies. Similar concerns were formulated by Papadopoulos and Giama [62] who noted that a detailed statement on the origins of the basic data used for the evaluation of the building components should be provided with any environmental study.

In addition, it is difficult to estimate the lifetime of most components. Hernandez and Kenny [60,61], like Kellenberger and Althaus [29], deplored the lack of reliable data on life span of building components, which becomes an important issue of LCA in low energy houses and buildings. Similar problem arise, with the lifetime of the building itself. To handle this problem, they suggest to refer to the norm ISO 15686 "Buildings and constructed assets - service-life planning" [63] or using a 50 years time frame as a reference for major renovations, since it is acknowledged and used in many studies [35].

Habert et al. [64] also criticized the methodology used for life cycle assessments of bulk materials used in buildings. Their concern is concentrated on state-pressure environmental indicators [65]. This type of environment indicator is calculated by comparing a flow of matter to a reference stock. They pointed out that one key weakness of this approach is the inappropriate account of the local and temporal variations of the stock. Using a methodology they have developed previously [66], they analyzed the depletion of aggregates, which are not normally considered to have a depletion potential. For example, while the depletion of bulk resources is negligible at global level $[67,68]$ and hard to put 
in evidence at the scale of a country like France, depletion becomes clear in a relatively small region like Île de France, where depletion time scale is the same order of magnitude than quarries or buildings lifetime.

In addition, to take account of the impact of power hungry industrial processes, which might be difficult to operate with a power mix dominated by renewable and distributed production, they developed an indicator of "power intensity" of materials. Instead of using the usual total energy consumption as an indicator of sustainability, they used the average of the power needed to produce materials pondered by their energy content [66]. This indicator does not have a true physical meaning but from an environmental point of view, it can be used when comparing two solutions to select the one who is the less dependent to high power processes.

To illustrate their idea, they compared the production and operation phases of three houses made respectively in stone masonry, in rammed earth, and in concrete. The details of the construction have been published by Morel et al. [69] and the energy needed during the use of the houses is estimated at $4,600 \mathrm{kWh} / \mathrm{yr}$ for a service life of 50 years. In these cases, while average energy consumption is rather uniform and dominated by the operation phase, the power indicator for the concrete house was 3.5 larger than the same house build in stone masonry and mortar. They also pointed out that energy consumption should also be considered on a territory-based approach as it was already proposed by Pulsili et al. [70].

\subsection{Post-occupancy Evaluation}

While some researchers critic the analysis of materials used, others raise doubts on the projection of those models. Meir et al. [71] reviewed the importance of post-occupancy evaluation in the optimization of the actual environmental trace of a building. Indeed, they noted that there is an ever increasing demand on comfort in buildings, while there is pressure to improve the energy efficiency [72]. A way to better fulfill these contradictory requirements is to have a better knowledge of the interaction of the user with the building itself. Indeed, occupant behaviors vary widely and can impact energy consumption by as much as $100 \%$ for a given dwelling [73].

For instance, they summarized three post-occupancy evaluation studies conducted in Germany on green buildings relative to thermal comfort and occupant satisfaction [74-76]. The results of these studies indicate that under specific conditions involving a high level of activity, occupants of those buildings could tolerate temperature settings outside the normal ones for an air-conditioned building. Such an increase in comfort range compared to air-conditioned buildings could be an easy energy efficiency application. However, this knowledge is not yet included in the green building design evaluation, which might lead to under optimized design. A similar phenomenon was observed for buildings with opening windows that increase the satisfaction of users [77-79]. However, windows optimization is tricky since large window can save on lighting and improve visual comfort [80], but not always since occupant can also suffer from glare and excessive heat [80,81].

\section{Construction Materials Environmental Trace}

Following the previous discussion, the reduction of embodied energy in construction materials is now as important as ever. To quote Bainbridge [82]: "An ideal building would be inexpensive to build, 
last forever with modest maintenance, but return completely to the earth when abandoned". In a recent review, Joseph and Tretsiakova-McNally [83] explored the alternate materials that could be used to reduce the environmental trace of a building.

\subsection{Concrete}

In the aforementioned perspective, concrete is regarded as one of the most energy intensive material. It is also a large source of $\mathrm{CO}_{2}$ emission, its production generating up to $7 \%$ of the world total emissions [84]. These emissions are not only produced by the energy used, but also $\mathrm{CO}_{2}$ is a byproduct of the necessary de-carbonation of limestone itself [85]. Consequently, concrete represents a large fraction of the environmental trace of the buildings. For instance, Asif et al. [14] calculated that 99\% of the total emitted $\mathrm{CO}_{2}$ resulting from a semi detached three bedrooms house in Scotland was originating from concrete and mortar.

Blenghini [37] noted that concrete recycling was permitting the recovery of only $19 \%$ of its embodied energy. This result complies with the observations of Gustavsson and Sathre [86], who also noted that, while the extraction of aggregate to be incorporated in concrete needed $20 \mathrm{~kJ} / \mathrm{kg}$ of oil and $9 \mathrm{~kJ} / \mathrm{kg}$ of electricity, crushing the same amount of concrete requires $120 \mathrm{~kJ}$ of oil and $50 \mathrm{~kJ}$ of electricity. In a later work [87], they noted that a small benefit of concrete recycling may occur when it is used to replace crushed stone. Another approach to reduce the environmental trace of concrete is to replace the natural aggregate with recycled products: recycled concrete aggregate, crushed blast furnace slag, sand, brick, glass, granulated plastics, waste fiberglass, mineralized wood shavings, etc. [83]. However, the integration of these materials is not straightforward as mechanical and chemical properties are different than those of the natural aggregates. In consequence, some adaptations of the concrete mixtures must be done to maintain the desired properties. Notwithstanding these problems, this type of concrete can be used in many applications. Examples include the renewal of Denver's Stapleton Airport in the US which reused and recycled 6.5 million tons of concrete [88].

An alternate strategy to improve the environmental behavior of concrete is to increase its mechanical strength which allows a reduction of the volume used for the same application [89]. With this objective in mind, an ultra high performance concrete Ductal ${ }^{\circledR}$ was developed in France. This concrete uses only $65 \%$ of raw materials, $51 \%$ of the primary energy, and $47 \%$ of the overall $\mathrm{CO}_{2}$ emissions of the traditional concrete. Its mechanical properties are also largely improved. Its compressive strength is 6-8 times higher, the flexural strength is 10 times higher, while the durability is from 10 to 100 times better [85].

Also, some authors explored the possibility of using alternate materials instead of concrete. For example, Huberman and Pearlmutter [30] calculated that the embodied energy of a house in the Negev desert could be reduced by $20 \%$ by substituting reinforced concrete by alternate materials such as hollow concrete blocks, stabilized soil blocks or fly-ashes. In a similar way, unfired bricks can be used instead of fired ones. The energy needed to produce unfired brick $(657.1 \mathrm{MJ} / \mathrm{t})$ is much lower than the one needed for the fired brick $(4,186.8 \mathrm{MJ} / \mathrm{t})$; a factor 6.4 in reduction [90]. This traditional building material is inexpensive and also involves good thermal and acoustic properties. Moreover, at the end of its useful life, it can be reused by grinding, wetting or can be simply returned to the ground. 
However, the unfired bricks lack of durability when exposed to water. Water damage limits their application but this problem can be alleviated by the addition of lime.

In some applications, stone can be used as a substitute for concrete or ceramic. If extracted locally and processed efficiently, stones can reduce the environmental impact of a construction. There is now a renewed interest in dry stone masonry. As many walls build in the 19th and at the beginning of the 20th century are aging, modern engineering tools are needed to assess their mechanical performances [91,92]. The environmental impact of natural stones and aggregates is extensively discussed by Calkins [84]. Stones can also be used as a replacement for ceramic. Nicoletti et al. [93] did a comparative LCA between marble and ceramic as a flooring material. Their analysis indicated that marble had an environmental trace 2.2 times less than ceramic in their specific environment.

\subsection{Metals}

Metals (steel, aluminum, copper, etc.) possess a very large embodied energy compared to concrete (aluminum $191 \mathrm{MJ} / \mathrm{kg}$, steel $32 \mathrm{MJ} / \mathrm{kg}$, concrete $1.30 \mathrm{MJ} / \mathrm{kg}$ ). In consequence, even if they represent a small fraction of the building mass, they largely contribute to its total embodied energy. As an example, Chen et al. [46] studied two high rise residential buildings in Hong Kong. In these cases, steel and aluminum together accounted for $\sim 75 \%$ of the overall embodied energy. However, relatively little concrete was used in the structure. Nevertheless, they noted that the embodied energy of the metal could be largely reduced by recycling. They pointed out that the energy intensity is about $10 \mathrm{MJ} / \mathrm{kg}$ for recycled steel and $8 \mathrm{MJ} / \mathrm{kg}$ for recycled aluminum, which is only $31 \%$ of energy intensity of the virgin steel and only $4 \%$ of that of the virgin aluminum. Blengini [37] and Gustavsson and Sathre [86] came to a similar conclusion, with slightly different numbers. In consequence, using recycled steel and aluminum can reduce the overall embodied energy by as much as $50 \%$.

Additional gains also arise at the end of life of the building by recycling those materials. However, as noted by Dodoo et al. [87], as the recycled fraction of metal in the feedstock is increased, the overall energy gain by end-of-life recycling is reduced. The potential energy recovery from recycling metals led Chen et al. [46] to recommend their usage as an alternative to concrete for non-structural elements of the building.

\subsection{Wood and Straw Bale}

While concrete is considered as an environmental burden, wood has a much better reputation. In that aspect, the literature is essentially unanimous to proclaim that the wood-based constructions have the lowest energy needs and $\mathrm{CO}_{2}$ emissions [94-105]. They are two main factors which explain the wood small environmental trace. Wood acts as a carbon storage material as long as the lifetime of the building is larger than the lifetime that the trees would have had if they were not cut $[97,98,102]$. In addition, wood can be used as a biofuel, which can replace fossil fuels. As noted by Gustavsson and Sathre [86], and Dodoo et al. [87] not only wood from a building could be recovered, but also all the wood residues from the extraction, manufacturing, and construction processes. However, this gain is real only if the forest exploitation protects its regeneration potential.

Nevertheless, while wood has low embodied energy, it needs often more energy in the construction process than steel. This is largely caused by the transportation of construction workers, which is a 
large contribution to the embodied energy. As a result, for some buildings, steel can have an even lower embodied energy than wood. While this might also be true for $\mathrm{CO}_{2}$ emissions, wood performs generally much better than steel for this environmental indicator due to its sequestration potential. This counter-intuitive result stresses the importance to consider steel as alternate option to wood $[102,106]$.

Another alternate construction material, that is the object of considerable interest, is the straw bale. It has been used as construction material around the world for centuries in place where wood was rare and grass abundant. Straw has many useful properties as a construction material [107]. It has excellent thermal and sound insulation properties. In addition, its production and processing requires little energy compared to other construction materials. While concerns have been raised about its long term reliability, careful construction processes can insure that its lifetime is not an issue in building application. As pointed out by Pierquet et al. [108], straw bale wall systems provide the best combination of higher insulating value and lower embodied energy. Still, more research is needed on the most effective way to integrate it in more classical building design.

\subsection{Windows and Radiative Thermal Control}

While traditional material might have some appeal to reduce the total environmental burden, advanced material and technique can also have a large impact of energy efficiency at a very low initial environmental cost. For example, Hannon [109] reported that a double glazing window can return 136 times the added embodied energy of a single window through its life time. Addition of low-emissivity coatings and utilization of argon or krypton in high performance windows reduces even more the heat and cooling loads with a minimum additional embodied energy [77,110,111]. For example, Blom et al. [112] noted that replacing existing single and regular double glazing with high efficiency double glazing provided a gain of a factor 40 in environmental impact compare to the additional resources requirement.

High solar reflectance coating is also an example of technology with a very high environmental return for a minimal investment. The adequate use of high reflectance paints can lower roof surfaces temperature by up to $10{ }^{\circ} \mathrm{C}$, which provides both gains in energy efficiency and improvements of the material life time [113]. Indeed, these coatings can largely (18-93\%) reduce the cooling load in air-conditioned buildings [114-116]. Overall, building energy consumption reduction is less impressive [117], but this technique also provides environmental gain not related to energy, like reduction of air pollution by reduction of the heat island effect [116].

\section{Building Retrofitting}

While most life cycle analyses of buildings have been done on new buildings, only $1 \%$ of the building stock is renewed annually [118]. Consequently, the short and medium terms environmental benefits must come from building retrofitting. In many case, this retrofitting would have to be done even without consideration for the energy efficiency since acceptable living conditions standards were much lower in the past or because some element of the building degraded over time [119]. These circumstances provide an opportunity to largely improve the energy efficiency of a building with a minimal addition of embodied energy. 
Nevertheless, there is not that many studies on the optimal approach to energy demand reduction when retrofitting a building [120]. The most effective way to reduce the energy consumption of a residential unit (house) is to improve the building envelope targeting passivhaus standard if feasible. From our own building retrofits experience, in commercial, institutional, and large residential buildings, the reduction in conflicts of operation between the building energy systems, namely heating and air conditioning, was found to be the most effective way to reduce energy consumption with a minimal investment.

Dodoo et al. [87] studied the impact of retrofitting a wood-frame house to passivhaus standard. They noted that the primary energy use during the operation phase still dominates after the retrofit. However, the relative importance of other phases of the life cycle was increased. Overall, the retrofit was positive since the primary energy payback period was less than four years. This is aligned with the results of Feist [44]. However, the importance of the gain (energy reduction) was strongly related to the source of energy used. In that case, they compared resistance heating and district heating. Since the source of electricity was not renewable, unlike the district heating, it had a larger environmental trace from the start. In consequence, environmental gains were found to be lower for district heating. This result is coherent with that of Gustavsson and Joelsson [53].

\section{Local Energy Production}

Some approaches used to reduce the environmental trace of buildings are based on the local production of energy. Nevertheless, the environmental trace of this local production must be compared to the environmental trace of the external energy production it replaces. This is a somewhat difficult task to carry-out but as a proxy, we can use the ratio between energy returned on energy invested (EROI). If the EROI is not available, the ratio between energy return payback period to the expected installation life time can be used in a similar way.

The higher this ratio, the lower the environmental impact per unit of energy is expected. It is likely to be also a better economic investment. In consequence, local production should be preferred if its EROI is higher than the average EROI of the external energy source, if we compare between two renewable energy sources [121,122]. Calculating the average EROI of an energy basket is somewhat tricky. Nevertheless, there is some indication that the average EROI of the US energy basket is close to 10 and that lower EROI have negative economic impacts [123]. In addition, this is the same ratio that has been observed for insulation by several researchers [42,52,54,87,124]. From both arguments, we can estimate that a local energy production from renewable sources that involves an EROI lower than 10 is not environmentally and economically effective, compare to a non local renewable energy source with an higher EROI or simply improving the insulation.

This is similar to the results obtained by Lu and Yang [125] that observed an energy payback time of $7.3 \mathrm{yr}$ for a rooftop integrated photovoltaic system. They also noted than this value varied with the orientation from 7.1 to 20 years. Laleman, Albrecht, and Dewulf [126] did a review of the environmental impact of residential photovoltaic systems in regions with a low solar irradiation: the EROI was 5 in Belgium/UK and 12 in Spain. Battisti and Corrado [127] also obtained similar results for a building integrated PV system, retrofitted on a tilted roof, located in Rome (Italy). In that case, environmental impacts avoided were 5 to 10 times larger than the environmental trace of the PV 
system. Radhi [128] estimated that the EROI of building integrated photovoltaic panels was 1.3-1.4 for a site in the United Arab Emirates. However, this ratio improved to 5.2-5.7 when including the reduction of building energy consumption due to an improved thermal envelope. It should be noted that variations in the technology used, the climatic conditions, and the basic assumptions make it difficult to compare results from different studies.

Since they have a smaller initial embodied energy solar, thermal collectors tend to have a shorter energy payback time and consequently a better EROI. Ardente et al. [129,130] estimated that the energy payback time was between 1.2 and $2.3 \mathrm{yr}$ for a solar domestic water heater installed in Palermo, Italy. For a domestic hot water system, in UK, Menzies and Roderick [131] report an energy payback time of 2.6 and 6.1 years. These values are a strong function of the latitude and exposure of the collector. This is consistent with the result of Crawford et al. [132] who found an energy payback period of $2.5 \mathrm{yr}$ in Brisbane, Australia.

The analysis of Leckner and Zmeureanu [124] reports than EROI of a combined thermal-PV solar panel system is 3.8, when the system is installed in Montreal, Canada. Hence, the utilization of the solar panel is likely to produce more pollution than using directly the energy from another more efficient renewable energy source. This is especially true in this case since, in Montreal, the solar irradiation is not very high and the electricity comes essentially from hydro-power. These results were in line with those of Gustavsson and Joelsson [53], who noted that the use of solar panels for water heating was always less efficient than using the heat pump or district heating. They noted that this was in contrast with previous results that recommended the utilization of electric heating for passivhaus [133-135].

We can conclude from the above investigations that even in the sunniest climates, distributed local energy production can make little environmental sense compared to investing a similar amount of resources in a large scale energy production facility. Care should therefore be taken before selecting such an approach.

\section{Unsteady Environment Indicators}

One of the key problems in building life cycle analysis arises from the long life of the buildings (30-100 yr). Over such a long period of time, the energy basket and even the climate are expected to change. This fact alone raises some concerns about the applicability of the standard LCA method for buildings [136-140]. The same observation was done by Pehnt [141] for renewable energy technologies. In parallel, Dixit et al. [6] noted the problematic nature of the aging of the LCA data, which creates inconsistencies between studies. In consequence, LCA in the construction sector cannot be applied without assumptions or additional refinements.

The change of the energy basket introduces far reaching consequences when the environmental trace is dominated by the energy consumption. Gustavsson and Joelsson [52], Dodoo et al. [87] and, Ortiz et al. [142] noted that the positive impact of a retrofit is highly dependent on the energy input. If we expect (or hope) that the environmental trace of the energy production will improve with time, predicted environmental trace gain for the introduction of a technology are to be lower than predicted from a static LCA perspective. This can have unexpected consequences for climate change mitigation policies. Kannan and Strachan [143] using the UK MARKAL and MARKAL-Macro energy-economic 
model, explored a range of scenario for reaching $60 \% \mathrm{CO}_{2}$ reduction for the whole country [144]. They noted that their model showed a huge variation in energy demand projection as a consequence of the uncertainty in model assumptions. Nevertheless, they noted than the most effective way to reduce $\mathrm{CO}_{2}$ emissions was to concentrate the effort on energy production [145,146] and not necessarily on energy efficiency.

An additional complexity comes from the climate changes themselves that will bring a reduction in heating loads and an augmentation of the cooling loads over the building life time. In a cold climate, this will bring an overall energy consumption reduction, while it will increase it in a hot climate [147].

\section{Conclusions}

This paper was intended to review the current investigations devoted to the guidelines for the design of new sustainable buildings as well as the retrofit of actual ones. It first states that historically, researchers mainly, if not solely, focused their attention on the reduction of the energy consumption of buildings during their operation phase, leading to the initial concept of zero energy buildings (ZEB). Then, the paper stresses this need to broaden the analysis to complementary ways to ensure sustainability over the life cycle of buildings namely through the phases of construction, commissioning, operation, maintenance, and decommissioning. From these considerations, the initial concept of ZEB evolved to include primary consumption energy first, then embodied energy, total energy, and, finally, to become a life-cycle ZEB or LCZEB. The paper shows that nowadays this concept still has to be refined, standardized, and acknowledged by the building community.

The proposed review also mentions that the occupants may play a preponderant role on the energy consumption requirements as the concept of comfort may strongly influence the actual temperature and humidity levels required in a typical building.

Then, the review attempts to discuss mainly the issue of materials used in the construction phase of a building lifecycle, while recycling impact is mentioned. The review discusses the high impact of concrete on the embodied energy and explores ways to either improve its trace or replace it by other materials such as unfired bricks and stone. The review stresses this need to avoid concrete as much as possible as it may, in some particular applications, account for $99 \%$ of the total energy embodied in a building. Windows are also briefly investigated as double-pane windows are found to be better that their single-pane counterparts over the life cycle of a building.

The conclusion about retrofitting is that for residential units the work on a better thermal envelope seems to be the best way to improve sustainability whereas for commercial, institutional and larger residential buildings, the appropriate control of the energy systems - to avoid antagonisms - is the first issue to consider.

When local energy production is concerned, the review points out that an EROI of 10 appears to be the minimum required to justify a local production when compared to large scale production (of renewable energy). Otherwise, the local production could be nonsense in terms of sustainability. Solar thermal heat recovery seems to be more sustainable than other systems.

Finally, the paper ends with warnings when it comes to the life cycle analysis (LCA) of long lasting products such a buildings. Over a long period of time (up to 100 years), LCA could be somewhat difficult to carry out as the climate, the regulations, the energy basket, and the comfort standards vary, 
introducing a temporal drift of the parameters used to define acceptable thresholds. The environmental footprint then varies temporally as well as geographically due to buildings extended lifetimes.

The temporal drift of fundamental parameters required in LCA was not much an issue with classical design as the instantaneous energy consumption dominates the total energy need. But, in low energy buildings - that is buildings of the future-where the operation phase characterized by energy consumption is lower, the unsteadiness of the parameters over a long period of time may play a much more important role. As a result, these parameters and their variation with time must be accounted for appropriately if we want to reduce the environmental trace of buildings further than it is now possible.

This is a necessary step to reach the goal of reduction by a factor three (Europe) to five (North America) of the buildings environmental footprint: a mandatory requirement to ensure a sustainable future.

\section{References}

1. Brundtland, G. Our Common Future: The World Commission on Environment and Development; Oxford University Press: Oxford, UK, 1987.

2. IPCC. Climate Change 2007: Mitigation; Contribution of Working Group III to the Fourth Assessment Report; Cambridge University Press: Cambridge, UK, 2007.

3. Kesselring, P.; Winter, C.J. World Energy Scenarios: A Two-kilowatt Society, Plausible Future or Illusion? In Proceedings of the Energietage 94, Villigen, Switzerland, 10-12 November 1994.

4. Pfeiffer, A.; Koschenz, M.; Wokaum, A. Energy and building technology for the $2000 \mathrm{~W}$ society-Potential of residential buildings in Switzerland. Energ. Build. 2005, 37, 1158-1174.

5. Schulz, T.F.; Kypreos, S.; Barreto, L.; Wokaum, A. Intermediate steps towards the $2000 \mathrm{~W}$ society in Switzerland: An energy-economic scenario analysis. Energ. Policy 2008, 36, 1303-1317.

6. Dixit, M.K.; Fernández-Solís, J.L.; Lavy, S.; Culp, C.H. Identification of parameters for embodied energy measurement: A literature review. Energ. Build. 2010, 42, 1238-1247.

7. Arena, A.P.; de Rosa, C. Life cycle assessment of energy and environmental implications of the implementation of conservation technologies in school buildings in Mendoza-Argentina. Build. Environ. 2003, 38, 359-368.

8. Horvath, A. Construction materials and the environment. Annu. Rev. Energ. Environ. 2004, 29, 181-204.

9. Urge-Vorsatz, D.; Novikova, A. Opportunities and costs of carbon dioxide mitigation in the worlds domestic sector. In Proceedings of the International Energy Efficiency in Domestic Appliances and Lighting Conference '06, London, UK, 21-23 June 2006.

10. Langston, Y.L.; Langston, C.A. Reliability of building embodied energy modeling: An analysis of 30 Melbourne case studies. Construct. Manag. Econ. 2008, 26, 147-160.

11. Lippiatt, B.C. Selecting cost effective green building products: BEES approach. J. Construct. Eng. Manag. 1999, 125, 448-455.

12. Tommerup, H.; Rose, J.; Svendsen, S. Energy-efficient houses built according to the energy performance requirements introduced in Denmark in 2006. Energ. Build. 2007, 39, 1123-1130. 
13. Ding, G. The Development of a Multi-criteria Approach for the Measurement of Sustainable Performance for Built Projects and Facilities. Ph.D. Thesis, University of Technology, Sydney, Australia, 2004.

14. Asif, M.; Muneer, T.; Kelley, R. Life cycle assessment: A case study of a dwelling home in Scotland. Build. Environ. 2007, 42, 1391-1394.

15. Campogrande, D. The European construction industry-facts and trends. In Proceedings of the ERA Convention, European Construction Industry Federation (FIEC), Berlin, Germany, 5-6 June 2007.

16. Report on the Proposal for a Directive of the European Parliament and of the Council on the Energy Performance of Buildings (recast); (COM(2008)0780-C6-0413/2008-2008/0223(COD)); European Parliament: Bruxelles, Belgium, 6 April 2009.

17. A National Programme for Energy Efficiency and Energy-smart Construction. Swedish Government Bill 2005/06:145. Available online: http://www.regeringen.se/sb/d/574/a/63635 (accessed on 1 February 2011).

18. Harvey, L.D.D. Reducing energy use in the buildings sector: Measures, costs, and examples. Energ. Effic. 2009, 2, 139-163.

19. Butti, K.; Perlin, J. Golden Thread, 2500 Years of Solar Architecture and Technology; Cheshire Books: Palo Alto, CA, USA, 1980.

20. Bliss, R.W. Design and performance of the nation's only fully solar-heated house. Air Cond. Heat. Vent. 1955, 52, 92.

21. Esbensen, T.V.; Korsgaard, V. Dimensioning of the Solar Heating System in the Zero Energy House in Denmark; United States: New York, NY, USA, 1977; pp. 195-199.

22. Besant, R.W.; Dumont, R.S.; Schoenau, G. The Saskatchewan conservation house: Some preliminary performance results. Energ. Build. 1979, 2, 163-174.

23. Schnieders, J.; Hermelink, A. CEPHEUS results: Measurements and occupant's satisfaction provide evidence for passive houses being an option for sustainable building. Energ. Policy 2006, 34, 151-171.

24. Wahlström, Å; Ruud, S.; Erlandsson, M.; Norrman, J.; Sandberg, E.; Wall, M.; Eek, H. A Classification of Passive House for Swedish Conditions, 2008. Available online: http://www.passivhuscentrum.se/fileadmin/pdf/Passive_house_definition_Sweden.pdf (accessed on 1 February 2011).

25. Janson, U. Passive Houses in Sweden-Experiences from Design and Construction Phase; Report EBD-T-08/9; Department of Architecture and Built Environment, Lund University: Lund, Sweden, 2008.

26. Boustead, I.; Hancock, G.F. Handbook of Industrial Energy Analysis; Chichester/John Wiley: New York, NY, USA, 1979.

27. Boustead, I. Eco-labels and Eco-indices. Do they make sense? Presented at the Fourth International Ryder Transpak Conference, Brussels, Belgium, 18-19 May 1999. Available online: http://www.boustead-consulting.co.uk/download/ryder99.pdf (accessed on 1 February 2011). 
28. Blengini, G.A.; Di Carlo, T. Evaluation of the environmental sustainability of a low energy residential building with the LCA methodology. In Proceeding of the 2nd International Seminar on Society and Materials (SAM2) 2008, Nantes, France, 24-25 April 2008.

29. Kellenberger, D.; Althaus, H.G. Relevance of simplifications in LCA of building components. Build. Environ. 2009, 44, 818-825.

30. Huberman, N.; Pearlmutter, D. A life-cycle energy analysis of building materials in the Negev desert. Energ. Build. 2008, 40, 837-848.

31. Badino, V.; Baldo, G. LCA, Istruzioni per l'Uso; Esculapio Publisher: Bologna, Italy, 1998.

32. Georgakellos, D.A. The use of the LCA polygon framework in waste management. Manag. Environ. Qual. Int. J. 2006, 17, 490-507.

33. Scheurer, C.; Keoleian, G.A.; Reppe, P. Life cycle energy and environmental performance of a new university building: Modeling challenges and design implications. Energ. Build. 2003, 35, 1049-1064.

34. Blengini, G.A.; Di Carlo, T. The changing role of life cycle phases, subsystems and materials in the LCA of low energy buildings. Energ. Build. 2010, 42, 869-880.

35. Sartori, I.; Hestnes, A.G. Energy use in the life cycle of conventional and low-energy buildings: A review article. Energ. Build. 2007, 39, 249-257.

36. Feist, W. Life-cycle energy balances compared: Low-energy house, passiv house, self-sufficient house. In Proceedings of the International Symposium of CIB W67, International Council for Building Research, Vienna, Austria, 4-10 August 1996; pp. 183-190.

37. Blengini, G.A. Life cycle of buildings, demolition and recycling potential: A case study in Turin-Italy. Build. Environ. 2009, 44, 319-330.

38. Ortiz, O.; Castells, F.; Sonnemann, G. Sustainability in the construction industry: A review of recent developments based on LCA. Constr. Build. Mater. 2009, 23, 28-39.

39. Blanchard, S.; Reppe, P. LCA of a Residential Home in Michigan; School of Natural Resources and Environment, University of Michigan: Ann Arbor, MI, USA, 1998; p. 60.

40. Adalberth, K.; Almgren, A.; Petersen, E.H. Life Cycle Assessment of four multi-family buildings. Int. J. Low Energy Sustain. Build. 2001, 2, 1-21.

41. Maddox, B.; Nunn, L. Life Cycle Analysis of Clay Brick Housing Based on a Typical Project Home; The Centre for Sustainable Technology, University of NewCastle: NewCastle, UK, 2003; p. 34 .

42. Winther, B.N.; Hestnes, A.G. Solar versus green: The analysis of a Norwegian row house. Sol. Energy 1999, 66, 387-393.

43. Ortiz, O.; Bonnet, C.; Bruno, J.C.; Castells, F. Sustainability based on LCM of residential dwellings: A case study in Catalonia, Spain. Build. Environ. 2009, 44, 584-594.

44. Feist, W. Life cycle energy analysis: Comparison of low-energy house, passiv house, self-sufficient house. In Arbeitskries kostengünstige Passivhaüser; Passive House Institute: Darmstadt, Germany, 1997; Protokollbandnr 8.

45. Thormark, C. A low energy building in a life cycle-its embodied energy, energy need for operation and recycling potential. Build. Environ. 2002, 37, 429-435.

46. Chen, T.Y.; Burnett, J.; Chau, C.K. Analysis of embodied energy use in the residential building of Hong Kong. Energy 2001, 26, 4, 323-340. 
47. Mithraratne, N.; Vale, B. Life cycle analysis model for New Zealand houses. Build. Environ. 2004, 39, 483-492.

48. Citherlet, S.; Defaux, T. Energy and environmental comparison of three variants of a family house during its whole life span. Build. Environ. 2007, 42, 591-598.

49. Treloar, G.; Fay, R.; Love, P.E.D.; Iyer-Raniga U. Analysing the life-cycle energy of an Australian residential building and its householders. Build. Res. Inf. 2000, 28, 184-195.

50. Dimoudi, A.; Tompa C. Energy and environmental indicators related to construction of office buildings. Resour. Conserv. Recy. 2008, 53, 86-95.

51. Goedkoop, M.; Spriensma, R. The Eco-indicator 99: A Damage Oriented Method for Life Cycle Assessment, 2nd ed.; Methodology Report; PRé Consultants B.V.: Amersfoort, The Netherlands, 2000.

52. Peuportier, B.L.P. Life cycle assessment applied to the comparative evaluation of single family houses in the French context. Energ. Build. 2001, 33, 443-450.

53. Gustavsson, L.; Joelsson, A. Life cycle primary energy analysis of residential buildings. Energ. Build. 2010, 42, 210-220.

54. Verbeeck, G.; Hens, H. Life cycle inventory of buildings: A contribution analysis. Build. Environ. 2010, 45, 964-967.

55. Bribián, I.Z.; Uséon, A.A.; Scarpellini, S. Life cycle assessment in buildings: State-of-the-art and simplified LCA methodology as a complement for building certification. Build. Environ. 2009, 44, 2510-2520.

56. Utama, A.; Gheewala, S.H. Indonesian residential high rise buildings: A life cycle energy assessment. Energ. Build. 2009, 41, 1263-1268.

57. Radhi, H. Can envelope codes reduce electricity and $\mathrm{CO}_{2}$ emissions in different types of buildings in the hot climate of Bahrain? Energy 2009, 34, 205-215.

58. Hernandez, P.; Kenny, P. From net energy to zero energy buildings: Defining life cycle zero energy buildings (LC-ZEB). Energ. Build. 2010, 42, 815-821.

59. Torcellini, P.; Pless, S.; Deru, M. Zero energy buildings: A critical look at the definition. In Proceedings of the American Council for Energy Efficient Economy Summer Study, Pacific Grove, CA, USA, 13-18 August 2006.

60. Hernandez, P.; Kenny, P. Zero Energy Houses and Embodied Energy: Regulatory and Design Considerations. In Proceedings of the American Society of Mechanical Engineering 2nd International Conference on Energy Sustainability, Jacksonville, FL, USA, 10-14 August 2008.

61. Hernandez, P.; Kenny, P. Defining Zero Energy Buildings-A life cycle perspective. In Proceedings of the PLEA 2008-25th Conference on Passive and Low Energy Architecture, Dublin, Ireland, 22-24 October 2008.

62. Papadopoulos, A.; Giama, E. Environmental performance evaluation of thermal insulation materials and its impact on the building. Build. Environ. 2007, 42, 2178-2187.

63. ISO 15686-8:2008. Buildings and Constructed Assets-Service-Life Planning-Part 8: Reference Service Life and Service-Life Estimation; International Organization for Standardization (ISO): Geneva, Switzerland, 2008.

64. Habert, G.; Bouzidi, Y.; Chen, C.; Jullien, A. Development of a depletion indicator for natural resources used in concrete. Resour. Conserv. Recy. 2010, 54, 364-376. 
65. Pulselli, R.M.; Simocini, E.; Pulselli, F.M.; Bastianoni, S. Emergy analysis of building manufacturing, maintenance and use: Em-builing indices to evaluate housing sustainability. Energ. Build. 2007, 39, 620-628.

66. Habert, G.; Castillo, E.; Morel, J.C. Sustainable Indicators for Resources and Energy in Building Construction. In Proceedings of the Second International Conference on Sustainable Construction Materials and Technologies, Ancona, Italy, 28-30 June 2010.

67. Guinée, J.B. Life Cycle Assessment: An Operational Guide to the ISO Standards; Kluwer Academic Publishers: Dordrecht, The Netherlands, 2002.

68. Van Oers, L.; de Koning, A.; Guinée, J.B.; Huppes, G. Improving Characterisation Factors for Abiotic Resource Depletion as Recommended in the New Dutch LCA Handbook; Roads and Hydraulic Engineering Institute: Leiden, The Netherlands, 2002.

69. Morel, J.C.; Mesbah, A.; Oggero, M.; Walker, P. Building houses with local materials: means to drastically reduce the environmental impact of construction. Build. Environ. 2001, 36, 1119-1126.

70. Pulselli, R.M.; Simocini, E.; Ridofi, R.; Bastianoni, S. Specific emergy of cement and concrete: An energy-based appraisal of building materials and their transport. Ecol. Indic. 2008, 8, 647-656.

71. Meir, I.A.; Garb, Y.; Jiao, D.; Cicelsky, A. Post-Occupancy Evaluation: An Inevitable Step Toward Sustainability. Adv. Build. Energy Res. 2009, 3, 189-220.

72. Zeiler, W.; Boxem, G. Sustainable schools: Better than traditional schools? In Proceedings of Indoor Air 2008 Conference, Copenhagen, Denmark, 17-22 August 2008; Paper ID 10.

73. Seryak, J.; Kissock, K. Occupancy and behavioral affects on residential energy use. In Proceedings of the ASES Solar 2003 Conference, Austin, TX, USA, 21-26 June 2003.

74. Gossauer, E.A.W. User Satisfaction at Workspaces: A Study in 12 Office Buildings in Germany; CISBAT: Lausanne, Switzerland, 2005.

75. Pfafferott, J.; Herkel, S.; Kalz, D.; Zeuschner, A. Comparison of low-energy office buildings in summer using different thermal comfort criteria. Energ. Build. 2007, 39, 750-757.

76. Wagner, A.; Gossauer, E.; Moosmann, C.; Gropp, T.; Leonhart, R. Thermal comfort and workplace occupant satisfaction: Results of field studies in German low energy office buildings. Energ. Build. 2007, 39, 758-769.

77. Menzies, G.F.; Wherrette, J.R. Windows in the workplace: Examining issues of environmental sustainability and occupant comfort in the selection of multi-glazed windows. Energ. Build. 2005, 37, 623-630.

78. Mahdavi, A.; Proeglhoef, C. Observation-based models of user control actions in buildings. In Proceedings of PLEA 2008-25th Conference on Passive and Low Energy Architecture 2008 Conference, Dublin, Ireland, 22-24 October 2008; Paper ID 169.

79. Mahdavi, A.; Kabir, E.; Mohammadi, A.; Lambeva, L. Occupants' evaluation of indoor climate and environmental control systems in office buildings. In Proceedings of Indoor Air 2008 Conference, Copenhagen, Denmark, 17-22 August 2008; paper ID 178.

80. Ito, H.; Yuming, W.; Watanabe, S.; Tanabe, S. Field survey of visual comfort and energy efficiency in various office buildings utilizing daylight. In Proceedings of Indoor Air 2008 Conference, Copenhagen, Denmark, 17-22 August 2008; Paper ID 309. 
81. Mochizuki, E.; Watanabe, S.; Kobayashi, K.; Wei, Y.; Tanabe, S.; Takai, H.; Shiratori, Y. Field measurement on visual environment in office building daylight from light-well in Japan. In Healthy Buildings: Creating a Healthy Environment for People, Proceedings of HB2006 International Conference, Lisbon, Portugal, 4-8 June 2006; Volume II, pp. 201-206.

82. Bainbridge, D.A. Sustainable building as appropriate technology. In Building without Borders: Sustainable Construction for the Global Village; Kennedy, J., Ed.; New Society Publishers: Gabriola Island, Canada, 2004; pp. 55-84.

83. Joseph, P.; Tretsiakova-McNally, S. Sustainable Non-Metallic Building Materials. Sustainability 2010, 2, 400-427.

84. Calkins, M. Materials for Sustainable Sites: A Complete Guide to the Evaluation, Selection, and Use of Sustainable Construction Materials; John Wiley \& Sons: Hoboken, NJ, USA, 2009.

85. Damtoft, J.S.; Lukasik, J.; Herfort, D.; Sorrentio, D.; Gartner, E.M. Sustainable development and climate change initiatives. Cement Concrete. Res. 2008, 38, 115-127.

86. Gustavsson, L.; Sathre, R. Variability in energy and carbon dioxide balances of wood and concrete building materials. Build. Environ. 2006, 41, 940-951.

87. Dodoo, A.; Gustavsson, L.; Sathre, R. Life cycle primary energy implication of retrofitting a wood-framed apartment building to passive house standard. Resour. Conserv. Recy. 2010, 54, 1152-1160.

88. Yelton, R. Concrete recycling takes off: The renewal of Denver's Stapleton Airport showcases concrete's place as a sustainable material. Concr. Producer 2004, 22, 28-31.

89. Habert, G.; Roussel, N. Study of two concrete mix-design strategies to reach carbon mitigation objectives. Cem. Concr. Comp. 2009, 31, 397-402.

90. Oti, J.E.; Kinuthia, J.M.; Bai, J. Engineering properties of unfired clay masonry bricks. Eng. Geol. 2009, 107, 130-139.

91. Colas, A.-S.; Morela, J.-C.; Garnier, D. Full-scale field trials to assess dry-stone retaining wall stability. Eng. Struct. 2010, 32, 1215-1222.

92 Mundell, C.; McCombie, P.; Heath, A.; Harkness, J. Behaviour of drystone retaining structures. Proc. Inst. Civil Eng. Struct. B. 2010, 163, 3-12.

93. Nicoletti, G.M.; Notarnicola, B.; Tassielli, G. Comparative Life Cycle Assessment of flooring materials: Ceramic versus marble tiles. J. Clean. Prod. 2002, 10, 283-296.

94. Koch, P. Wood versus non-wood materials in US residential construction: Some energy-related global implications. Forest Prod. J. 1992, 42, 31-42.

95. Buchanan, A.H.; Honey, B.G. Energy and carbon dioxide implications of building construction. Energ. Build. 1994, 20, 205-217.

96. Cole, R.J.; Kernal, P.C. Life cycle energy use in office buildings. Build. Environ. 1996, 31, 307-317.

97. Buchanan, A.H.; Levine, S.B. Wood-based building materials and atmospheric carbon emissions. Environ. Sci. Policy 1999, 2, 427-437.

98. Börjesson, P.; Gustavsson, L. Greenhouse gas balances in building construction: Wood versus concrete from life cycle and forest land use perspectives. Energ. Policy 2000, 28, 575-588. 
99. Goverse, T.; Hekkert, M.P.; Groenewegen, P.; Worrell, E.; Smits, R.E.H.M. Wood innovation in the residential construction sector; opportunities and constraints. Resour. Conserv. Recy. 2001, 34, 53-74.

100. Lenzen, M.; Treloar, G. Embodied energy in buildings: Wood versus concrete-reply to Borjesson and Gustavsson. Energ. Policy 2002, 30, 249-255.

101. Scharai-Rad, M.; Welling, J. Environmental and Energy Balances of Wood Products and Substitutes; Food and Agricultural Organization of the United Nations: Rome, Italy, 2002.

102. Lippke, B.; Wilson, J.; Perez-Garcia, J.; Bowyer, J.; Meil, J. CORRIM: Life-cycle environmental performance of renewable building materials. Forest Prod. J. 2004, 54, 8-19.

103. Perez-Garcia, J.; Lippke, B.; Briggs, B.; Wilson, J.; Bowyer, J.; Meil, J. The environmental performance of renewable building materials in the context of residential construction. Wood Fiber Sci. 2005, 37, 3-17.

104. Petersen, A.K.; Solberg, B. Environmental and economic impacts of substitution between wood products and alternative materials: A review of micro-level analyses from Norway and Sweden. Forest. Pol. Econ. 2005, 7, 249-259.

105. Upton, B.; Miner, R.; Spinney, M.; Heath, L.S. The greenhouse gas and energy impacts of using wood instead of alternatives in residential construction in the United States. Biomass Bioenerg. 2008, 32, 1-10.

106. Cole, R.J. Energy and greenhouse gas emissions associated with the construction of alternative structural systems. Build. Environ. 1999, 34, 335-348.

107. King, B. Design of Straw Bale Buildings: The State of the Art; Green Building Press: San Raphael, CA, USA, 2007; p. 296.

108. Pierquet, P.; Bowyer, J.L.; Huelman, P. Thermal performance and embodied energy of cold climate wall systems. Forest Prod. J. 1998, 48, 53-60.

109. Hannon, B. The energy cost of energy. In Energy, Economics and the Environment: Conflicting Views of an Essential Interrelationship; Daly, H.E., Umaña, A.F., Eds.; Westview Press: Boulder, CO, USA, 1981.

110. Robinson, P.D.; Hutchins, M.G. Advanced glazing technology for low energy buildings in the UK. Renew. Energ. 1994, 5, 298-309.

111. Aydin, O. Determination of optimum air-layer thickness in double-pane windows. Energ. Buld. 2000, 32, 303-308.

112. Blom, I.; Itard, L.; Meijer, A. Environmental impact of dwellings in use: Maintenance of façade components. Build. Environ. 2010, 45, 2526-2538.

113. Uemoto, K.L.; Sato, N.M.N.; John, V.M. Estimating thermal performance of cool colored paints. Energ. Build. 2010, 42, 17-22.

114. Akbari, H.; Levinson, R.; Rainer, L. Monitoring the energy-use effects of cool roofs on California commercial buildings. Energ. Build. 2005, 37, 1007-1016.

115. Synnefa, A.; Santamouris, M.; Akbari, H. Estimating the effect of using cool coatings on energy loads and thermal comfort in residential buildings in various climatic conditions. Energ. Build. 2007, 39, 1167-1174. 
116. Levinson, R.; Akbari, H. Potential benefits of cool roofs on commercial buildings: Conserving energy, saving money, and reducing emission of greenhouse gases and air pollutants. Energ. Effic. 2010, 3, 53-109.

117. Jo, J.H.; Carlson, J.D.; Golden, J.S.; Bryan, H. An integrated empirical and modeling methodology for analyzing solar reflective roof technologies on commercial buildings. Build. Environ. 2010, 45, 453-460.

118. Housing Statistics in the European Union 2005/2006; Federcasa, Italian Housing Federation, Eds.; Ministry of Infrastructure of the Italian Republic: Rome, Italy, 2006; p. 146.

119. Balaras, C.A.; Droutsa, K.; Argiriou, A.A.; Asimakopoulos, D.N. Potential for energy conservation in apartment buildings. Energ. Build. 2000, 31, 143-154.

120. Hermelink, A.H. How Deep to Go: Remarks on How to Find the Cost-optimal Level for Building Renovation; Report Commissioned by European Council for an Energy Efficient Economy; Ecofys GmbH: Köln, Germany,, 2009.

121. Mulder, K.; Hagens, N.J. Energy return on investment: toward a consistent framework. AMBIO 2008, 37, 74-79.

122. Gagnon, L. Civilisation and energy payback. Energ. Policy 2008, 36, 3317-3322.

123. Hall, C.A.S.; Balogh, S.; Murphy, D.J.R. What is the Minimum EROI that a Sustainable Society Must Have? Energies 2009, 2, 25-47.

124. Leckner, M.; Zmeureanu, R. Life cycle cost and energy analysis of a Net Zero Energy House with solar combisystem. Appl. Energ. 2011, 88, 232-241.

125. Lu, L.; Yang, H.X. Environmental payback time analysis of a roof-mounted building-integrated photovoltaic (BIPV) system in Hong Kong. Appl. Energ. 2010, 87, 3625-3631.

126. Laleman, R.; Albrecht, J.; Dewulf, J. Life Cycle Analysis to estimate the environmental impact of residential photovoltaic systems in regions with a low solar irradiation. Renew. Sustain. Energ. Rev. 2011, 15, 267-281.

127. Battisti, R.; Corrado, A. Evaluation of technical improvements of photovoltaic systems through life cycle assessment methodology. Energy 2005, 30, 952-967.

128. Radhi, H. Energy analysis of façade-integrated photovoltaic systems applied to UAE commercial buildings. Sol. Energy 2010, 84, 2009-2021.

129. Ardente, F.; Beccali, G.; Cellura, M.; Brano, V.L. Life cycle assessment of a solar thermal collector. Renew. Energ. 2005, 30, 1031-1054.

130. Ardente, F.; Beccali, G.; Cellura, M.; Brano, V.L. Life cycle assessment of a solar thermal collector: Sensitivity analysis, energy and environmental balances. Renew. Energ. 2005, 30, 109-130.

131. Menzies, G.F.; Roderick, Y. Energy and carbon impact analysis of a solar thermal collector system. Int. J. Sustain. Eng. 2010, 3, 9-16.

132. Crawford, R.H.; Treloar, G.J.; Ilozor, B.D.; Love, P.E.D. Comparative greenhouse emissions analysis of domestic solar hot water systems. Build. Res. Inf. 2003, 31, 34-47.

133. Feist, W.; Schnieders, J.; Dorer, V.; Haas, A. Re-inventing air heating: Convenient and comfortable within the frame of the passive house concept. Energ. Build. 2005, 37, 1186-1203.

134. Thyholt, M.; Hestnes, A.G. Heat supply to low-energy buildings in district heating areas analyses of $\mathrm{CO}_{2}$ emissions and electricity supply security. Energ. Build. 2008, 40, 131-139. 
135. Spät, P. District heating and passive houses - interfering strategies towards sustainable energy systems. In Proceedings of the 4S/EASST Conference 2004, Paris, France, 25-28 August 2004.

136. Energy Technology Availability: Review of Longer Term Scenarios for Development and Deployment of Climate-friendly Technologies; Massachusetts Institute of Technology Energy Laboratory: Cambridge, MA, USA, 1997.

137. Gregory, A.N.; Yost, P. A transparent, interactive software environment for communicating life cycle assessment results: An application to residential windows. J. Indus. Ecol. 2002, 5, 15-28.

138. Paulsen, J.H.; Borg, M. A building sector related procedure to assess the relevance of the usage phase. Int. J. Life Cycle Assess. 2003, 8, 142-150.

139. Johnston, D. A Physically Based Energy and Carbon Dioxide Emission Model of the UK Housing Stock; Ph.D. Thesis, Leeds Metropolitan University, Leeds, UK, 2003.

140. Khasreen, M.M.; Banfill, P.F.G.; Menzies, G.F. Life-Cycle Assessment and the Environmental Impact of Buildings: A Review. Sustainability 2009, 1, 674-701.

141. Pehnt, M. Dynamic life cycle assessment (LCA) of renewable energy technologies. Renew. Energ. 2006, 31, 55-71.

142. Ortiz, O.; Castells, F.; Sonnemann, G. Operational energy in the life cycle of residential dwellings: The experience of Spain and Colombia. Appl. Energ. 2010, 87, 673-680.

143. Kannan, R.; Strachan, N. Modelling the UK residential energy sector under long-term decarbonisation scenarios: Comparison between energy systems and sectoral modelling approaches. Appl. Energ. 2009, 86, 416-428.

144. Strachan, N.; Kannan, R.; Pye, S. Final Report on DTI-DEFRA Scenarios and Sensitivities Using the UK MARKAL and MARKAL-macro Energy System Models; UKERC Research Report, 2007. Available online: http://www.ukerc.ac.uk/support/tiki-download_file.php?fileId=205 (accessed on 1 February 2011).

145. Kannan, R.; Strachan, N. Uncertainties in exploring the UK low carbon energy system: Sensitivities analysis in power sector using MARKAL energy system model. In Proceedings of the BIEE Conference, Oxford, UK, 24-25 September 2008.

146. Strachan, N.; Kannan, R. Hybrid modelling of long-term carbon reduction scenarios for the UK. Energ. Econ. 2008, 30, 2947-2963.

147. Chaumont, D.; Angers, J.-F.; Frigon, A.; Pacher, G.; Roy, R. Évolution des conditions climatiques au Québec, Développement d'un scenario climatique utilisé à des fins de prévision de la demande d'électricité au Québec sur l'horizon 2030; Consortium Ouranos: Montreal, Canada, 2007. Available online: http://www.ouranos.ca/media/publication/43_Rapport_ Chaumont_climat_2007.pdf (accessed on 1 February 2011).

(C) 2011 by the authors; licensee MDPI, Basel, Switzerland. This article is an open access article distributed under the terms and conditions of the Creative Commons Attribution license (http://creativecommons.org/licenses/by/3.0/). 